\title{
Praktik Akuntabilitas Masjid: Studi Kasus pada Masjid Al-Akbar Surabaya
}

\author{
Uun Dwi Al Muddatstsir \\ Institut Agama Islam Negeri Zawiyah Cotkala Langsa \\ Email: uundwi@gmail.com
}

\section{Dessy Noor Farida}

Universitas Islam Negeri (UIN) Walisongo Semarang

Email: dessy_nf@walisongo.ac.id

\section{Early Ridho Kismawadi}

Institut Agama Islam Negeri Zawiyah Cotkala Langsa

Email: kismawadi@gmail.com

\begin{abstract}
This study aims to determine the practice of accountability carried out by the management of Al-Akbar Mosque in Surabaya. Accountability is needed as a form of organizational management responsibility to worshipers. The method used in this study is qualitative with a case study approach. The results of the study indicate that the manager has prioritized the interests and prosperity of the mosque compared to individual interests. Research also shows that accountability practices are carried out using honesty and legal accountability, process accountability, program accountability and financial policy accountability.
\end{abstract}

Keywords: Accountability; Mosques; Stewardship

\begin{abstract}
Abstrak: Penelitian ini bertujuan untuk mengetahui praktik akuntabilitas yang dilakukan oleh pengurus Masjid Al-Akbar Surabaya. Akuntabilitas sangatlah dibutuhkan sebagai bentuk tanggung jawab pengelola organisasi kepada jamaah. Metode yang digunakan dalam penelitian ini adalah kualitatif dengan pendekatan studi kasus. Hasil penelitian menunjukkan pengelola sudah mementingkan kepentingan dan kemakmuran masjid dibandingkan kepentingan individu. Penelitian juga menunjukkan praktik akuntabilitas yang dijalankan menggunakan akuntabilitas kejujuran dan hukum, akuntabilitas proses, akuntabilitas program dan akuntabilitas kebijakan keuangan.
\end{abstract}

Kata Kunci: Akuntabilitas; Masjid; Stewardship

Economica: Jurnal Ekonomi Islam - Volume 9, Nomor 2 (2018) 
Uun Dwi Al Muddatstsir, Dessy Noor Farida, Early Ridho Kismawadi

\section{Pendahuluan}

Akuntabilitas adalah cara untuk bertanggung jawab atas keberhasilan atau kegagalan melaksanakan misi organisasi untuk mencapai tujuan dan sasaran yang sudah diatur sebelumnya, melalui suatu media pertanggungjawaban yang dilaksanakan secara periodik (Mardiasmo 2006). Islam juga telah mengharuskan akuntabilitas sebagaimana yang telah dijelaskan di dalam Al-Quran surah Al Baqarah ayat 282.

Pada tahun 2015 Masjid Al-Akbar Surabaya (MAS) mengelola dana yang berasal dari dana bantuan donatur, kotak infaq, infaq penggunaan fasilitas MAS, infaq santri lembaga pendidikan, dan infaq lain-lain sejumlah Rp.13.970.818.095, jumlah yang tergolong sangat besar dan membutuhkan pengelolaan dan pencatatan yang baik agar bisa dipertanggungjawabkan penggunaannya kepada seluruh stakeholder. Dalam hal ini S, Olusola, dan Abiodun (2013), menambahkan bahwa apapun bentuk kepemilikan organisasi membutuhkan pengelolaan yang sesuai terhadap aktifitasnya demi terciptanya pertanggung jawaban yang baik.

Penelitian terkait akuntabilitas sudah pernah dilakukan untuk mengungkap keterkaitan akuntabilitas dan agama. Penelitian sejenis ini telah dilakukan oleh Kiswanto and Mukhibad (2011); Triyuwono and Roekhuddin (2000); Randa et al. (2011). Penelitian tersebut fokus pada keterkaitan antara akuntansi dan akuntabilitas dalam pengelolaan organisasi secara spiritual. Sedangkan penelitian di organisasi Islam telah dilakukan Simanjuntak dan Januarsi (2011); Putri (2013); Hanafi (2015), yang menjelaskan bahwa bahwa pengelola organisasi keagamaan sangat memahami pentingnya transparansi sebagai bentuk wujud akuntabilitas namun masih memiliki kekurangan dalam hal sumber daya manusia yang lemah dalam memahami akuntabilitas yang baik di organisasinya. Penelitian yang dilakukan oleh Sari, Mintarti, dan Fitria (2018) di Masjid Baburrahmah Samarinda memfokuskan pada akuntabilitas berbasis keadilan dan Clash of 
Jurisdictional Theory dan teori yang digunakan dalam penelitian ini adalah Sharia'te Enterprise Theory (SET). Sedangkan penelitian yang dilakukan oleh Sari, Mintarti, dan Fitria (2018) menitikberatkan pada akuntabilitas formal dan informal pada beberapa masjid di Kalimantan Timur.

Sebagai organisasi yang mengelola dana sumbangan dari masyarakat umum, organisasi keagamaan seperti masjid sudah seharusnya mengelola dana yang masuk dan melaporkannya secara rinci agar bisa dipertanggungjawabkan dalam penggunaan dana yang sudah diamanahkan oleh para penyumbang kepada pengurus organisasi keagamaan tersebut agar tidak terjadinya fitnah. Akuntabilitas bukan hanya tentang kepatuhan terhadap hukum atau standar yang berlaku, tetapi lebih kepada tujuan organisasi dan kepercayaan publik. Pemimpin organisasi nirlaba didorong untuk lebih memerhatikan bentuk strategi akuntabilitas yang dapat membantu mereka untuk mencapai misi mereka mendirikan organisasi tersebut demi menciptakan kepercayaan public (Ebrahim 2003).

Untuk mendapatkan kepercayaan publik atas pengelolaan organisasi keagamaan masjid, pihak pengelola sudah seharusnya mempertanggungjawabkan atas apa yang sudah dilaksanakan dalam mengelola masjid. Hal yang akan dikaji dalam penelitian ini adalah untuk mengetahui praktik akuntabilitas kejujuran dan hukum, akuntabilitas proses, akuntabilitas hukum dan kebijakan keuangan yang dilaksanakan oleh pengurus Masjid Al-Akbar Surabaya. Dari akuntabilitas tersebut bisa terlihat apakah praktik akuntabilitas yang dilaksanakan oleh pengurus masjid sudah sesuai dengat teori stedwarship, yaitu mengutamakan kepentingan organisasi bukan kepentingan pribadi. Karena praktik akuntabilitas yang baik di masjid dapat meningkatkan kepercayaan publik terhadap pengelola masjid dalam mengelola dana yang salah satunya bersumber dari jamaah. 


\section{Landasan Teori}

Teori yang mendasari penelitian ini adalah teori Donaldson dan Davis (1991) yang menjelaskan situasi dimana pihak manajemen bertindak bukanlah termotivasi oleh tujuan-tujuan individu, tetapi lebih ditujukan pada hasil utama manajemen untuk kepentingan perusahaan. Dalam teori ini dijelaskan bahwa adanya asumsi filosofis mengenai sifat manusia yang pada hakekatnya dapat dipercaya, mampu bertindak dengan penuh tanggungjawa, memiliki integritas dan kejujuran terhadap pihak lain. Dengan kata lain, pihak manajemen dapat dipercaya untuk bertindak dengan sebaikbaiknya bagi kepentingan publik maupun stakeholder (Kaihatu 2006). Implikasi teori stewardship terhadap penelitian ini, dapat menjelaskan eksistensi masjid sebagai lembaga yang dapat dipercaya dan bertindak sesuai dengan kepentingan publik dengan melaksanakan tugas dan fungsinya dengan tepat untuk kesejahteraan publik.

Akuntabilitas merupakan sebagai bentuk kewajiban mempertanggungjawabkan keberhasilan atau kegagalan pelaksanaan misi organisasi dalam mencapai tujuan dan sasaran yang telah ditetapkan sebelumnya, melalui suatu media pertanggungjawaban yang dilaksanakan secara periodik (Mardiasmo 2006). Menurut Sari, Mintarti, dan Fitria (2018) akuntabilitas merupakan suatu bentuk dari pertanggugjawaban dari suatu entitas terhadap tanggungjawab yang diperoleh, khususnya dalam mengelola keuangan suatu entitas atau organisasi yang biasanya digunakan oleh pengguna informasi keuangan entitas yang berasal dari eksternal entitas tersebut.

Menurut Ellwood (1993) terdapat empat dimensi akuntabilitas publik yang harus dipenuhi organisasi sektor publik, yaitu:

1. Akuntabilitas Kejujuran dan Akuntabilitas Hukum. Akuntabilitas kejujuran (accountability for probity) terkait dengan penghindaran penyalahgunaan jabatan (abuse of power), sedangkan akuntabilitas 
hukum (legal accountability) terkait dengan jaminan adanya kepatuhan terhadap hukum dan peraturan lain yang disyaratkan dalam penggunaan sumber dana publik.

2. Akuntabilitas Proses. Akuntabilitas proses terkait dengan apakah prosedur yang digunakan dalam melaksanakan tugas sudah cukup baik dalam hal kecukupan sistem informasi akuntansi, sistem informasi manajemen, dan prosedur administrasi. Akuntabilitas proses termanifestasikan melalui pemberian pelayanan publik yang cepat, responsif, dan murah biaya. Pengawasan dan pemeriksaan terhadap pelaksanaan akuntabilitas proses dapat dilakukan, misalnya dengan memeriksa ada tidaknya markup dan pungutan-pungutan lain di luar yang ditetapkan, serta sumber-sumber inefisiensi dan pemborosan yang menyebabkan mahalnya biaya pelayanan publik dan kelambanan dalam pelayanan.

3. Akuntabilitas Program. Akuntabilitas program terkait dengan pertimbangan apakah tujuan yang ditetapkan dapat dicapai atau tidak, dan apakah telah mempertimbangkan alternatif program yang memberikan hasil yang optimal dengan biaya yang minimal.

4. Akuntabilitas Kebijakan. Akuntabilitas kebijakan terkait dengan pertanggungjawaban pemerintah, baik pusat maupun daerah.

\section{Metode Penelitian}

Penelitian ini merupakan studi kasus (case study) dengan jenis disciplined comparative yang mencoba membandingkan antara masalah dan teori yang digunakan dalam penelitian (Kamayanti 2016). Studi kasus merupakan penelitian non mainstream (kualitatif) yang lebih menekankan pada proses dimana peneliti harus berinteraksi secara reguler dengan subjek penelitian di dalam lokasi penelitian, serta berfokus pada pemahaman, dan penafsiran peneliti atas objek penelitian (Basuki 2016). Pendekatan studi 
kasus dalam penelitian ini berguna untuk mengungkapkan akuntabilitas yang dilakukan oleh pengurus Masjid Al-Akbar Surabaya.

Penelitian ini bersifat kualitatif, yang bertujuan untuk mengungkapkan informasi kualitatif sehingga lebih menekankan pada masalah proses dan makna dengan mendeskripsikan sesuatu masalah (Sugiyono 2012). Penelitian ini juga bersifat deskriptif yaitu untuk mengungkapkan dan menggambarkan objek dan subjek penelitian apa adanya, dimana peneliti akan mengunggapkan hasil dari temuan penelitian sesuai fakta di lapangan.

Ruang lingkup penelitian terfokus pada Masjid Nasional Al Akbar Surabaya yang beralamat di jalan Masjid Timur No. 1 Surabaya. Dalam penelitian ini dibatasi pada permasalahan praktik akuntabilitas dilihat dari dimensi akuntabilitas kejujuran dan hukum, akuntabilitas proses, akuntabilitas program, dan akuntabilitas keuangan yang dikonsepkan oleh Mardiasmo (2000) untuk menjaga kepercayaan publik terhadap pengelolaan MAS.

Tabel 1. Daftar Informan Penelitian

\begin{tabular}{cll}
\hline No & Nama Informan & Jabatan \\
\hline 1 & H. Soedarto & Kabid Keuangan \\
\hline 2 & Hendro Tjahjono & Kabid Usaha dan Humas \\
\hline 3 & Alfian, SE & $\begin{array}{l}\text { Bagian Akuntansi dan Bagian Penerimaan \& } \\
\text { Kabid infak }\end{array}$ \\
\hline 4 & Nurfadillatul zunaida & Bendahara Pengeluaran \\
\hline 5 & Dani & Arsitek/ Jamaah \\
\hline
\end{tabular}

Sumber: Hasil Wawancara

Untuk memperoleh informasi dan data yang akan diolah dalam penelitian ini, maka data-data diperoleh dengan wawancara, pengamatan dan dokumentasi. Wawancara menggunakan metode semi structured agar 
suasana tidak menjadi formal, lebih mengarah pada percakapan. Media yang dipakai adalah alat perekaman yang kemudian ditraskipkan dengan catatan tertulis. Proses wawancara dilakukan secara mendalam (in-dept interview) yaitu dengan melakukan tanya jawab sambil bertatap muka antara peneliti dan informan yang terlibat dengan menggunakan pedoman wawancara agar wawancara tidak keluar dari topik yang sedang diteliti. Dapat dilihat pada Tabel 1. Peneliti mewawancarai langsung pihak-pihak yang terlibat dalam penelitian ini seperti pengurus bidang keuangan, staf akuntansi, bendahara pengeluaran, Kepala bidang usaha dan humas, administrasi dan jamaah masjid. Wawancara tersebut dilakukan pada tanggal 3 Januari 2017 di sekretariat Masjid Al-Akbar Surabaya.

Pengamatan dilakukan secara bebas yang bertujuan untuk menyajikan gambaran realistik perilaku saat melakukan aktifitas pekerjaan seperti menghitung kotak infak serta membuat berita acara penghitungan. Pengamatan juga dilakukan terhadap publikasi keuangan masjid dan kejadian lainnya untuk membantu menjawab pertanyaan penelitian. Dalam penelitian ini observer dapat melihat secara langsung kejadian secara apa adanya.

Dokumentasi diperoleh dari mempelajari bahan kepustakaan seperti jurnal yang terkait dengan akuntabilitas pada organisasi keagamaan, serta peraturan dan keputusan terkait penetapan pengelolaan organisasi Masjid oleh pihak yang berwenang.

Analisis data kualitatif dilakukan pada data yang sudah diperoleh dari hasil wawancara peneliti dengan pengurus MAS lalu kemudian dianalisis sehingga menjadi suatu temuan. Data yang diperoleh antara lain laporan rencana dan realisasi anggaran penerimaan dan belanja masjid (RAPBM), laporan neraca masjid, laporan keuangan surplus defisit, data mekanisme penggunaan fasilitas dan form biaya penyewaan, formulir permohonan pemakaian fasilitas dan kuitansi kas masuk yang akan dianalisis. Tahapan 
analisisnya sebagai berikut: Pengumpulan data baik dokumen, arsip, informasi lainnya akan diseleksi sesuai dengan kebutuhan peneliti.

Data hasil wawancara dengan pengurus MAS serta observasi yang telah dilakukan akan disusun secara sistematis dan selanjutnya akan diseleksi untuk mendapatkan data yang baik sesuai dengan keperluan penelitian. Penerapan akuntabilitas pada MAS akan dibandingkan dengan penelitian terdahulu terkait entitas nirlaba, serta data yang telah dikumpulkan akan dianalisis untuk mendapatkan suatu kesimpulan yang dapat dijadikan sebagai bahan evaluasi oleh MAS dan organisasi keagamaan lainnya agar terciptanya akuntabilitas yang baik demi memakmurkan masjid.

\section{Hasil dan Pembahasan}

\section{Akuntabilitas Kejujuran dan Hukum}

Dimensi atau bentuk akuntabilitas yang pertama dalam MAS yang akan dibahas adalah akuntabilitas kejujuran dan hukum. Seluruh pengurus Masjid Al Akbar Surabaya adalah muslim yang meyakini keberadaan Allah Swt. Namun masih adanya kejadian-kejadian ketidakjujuran membuat keimanan seseorang itu dipertanyakan. Akuntabilitas kejujuran dibutuhkan untuk melihat sejauh mana pengelola masjid tarkait motivasi kejujuran dalam menerima amanah sebagai pengurus masjid dengan penghasilan yang diketahui di bawah rata-rata pekerjaan di organisasi lain.

Pendapatan yang sesuai sangat penting untuk bisa menjauhkan dari tindak kecurangan yang dilakukan oleh pengurus, dengan pendapatan yang tidak sesuai maka akan sangat memungkinkan untuk para pengelola melakukan tindakan yang mengarah kepada hal yang merugikan masjid seperti penggelapan dana sedekah dan sebagainya. Dari hasil wawancara diketahui bahwa pengelola masjid pernah berfikiran untuk keluar dan mencari pekerjaan lain karena malu dengan istri. Sebagai contoh, 
penghasilannya Kabid Akuntansi dan Bendahara pengeluaran sekaligus infak hanya setengah dari penghasilan istri.

Diketahui bahwa para pegawai di Masjid Al Akbar Surabaya bekerja semata-mata tidak mengharapkan gaji namun dilakukan dengan sukarela dan penuh keikhlasan. Namun walaupun demikian dengan penghasilan yang di bawah UMR menurut peneliti tidak sesuai dengan pekerjaan mereka yang cukup banyak dan seringkali mengorbankan waktu libur untuk tetap bisa melaksanakan kegiatan pekerjaan di masjid. Hal ini dapat memicu tindakan ketidakjujuran yang dilakukan oleh pengelola masjid tersebut. Sebaliknya, penghasilan yang sesuai dengan apa yang telah pengelola lakukan untuk masjid akan memicu untuk pengelola tersebut agar bisa bekerja dengan lebih baik.

Asumsi dasar teori Stewrdship tentang pengelola sebagai penerima amanah/pengelola sangat terlihat, walaupun begitu besar tanggung jawabnya dalam mengelola masjid tetap ikhlas dan tulus melayani masyarakat umum dan jamaah yang memiliki kepentingan di masjid. Walaupun penghasilan yang cukup rendah tersebut tidak sebanding dengan apa yang telah mereka lakukan, dan walaupun para pengelola masjid tidak meminta imbalan besar, namun sebaiknya pihak direksi bisa lebih mempertimbangkan kembali untuk dapat menambah penghasilan untuk pengelola karena tambahan penghasilan tersebut akan membuat karyawan lebih maksimal dalam bekerja.

Selanjutnya akuntabilitas hukum dibutuhkan untuk mengetahui sejauh mana pertanggungjawaban yang dilakukan oleh pengurus MAS terkait akuntabilitas hukum. Di mana masjid yang berstatus Nasional berdasarkan SK Menteri No. 301 tahun 2003 menjadikan MAS menjadi masjid di bawah kewenangan pemerintah Provinsi Jawa Timur yang memiliki kekuatan hukum untuk mengetahui siapa yang berwenang dan bertanggung jawab secara langsung dalam segala aspek pengelolaannya, berbeda dengan masjid yang dikelola oleh suatu yayasan tertentu.

Economica: Jurnal Ekonomi Islam - Volume 9, Nomor 2 (2018) 
Pengangkatan pengelola MAS tahun 2015 diatur dalam SK Gubernur No. 188/288/KPTS/013/2016 tentang badan pengelola MAS periode tahun 2015-2018. Oleh karena itu peran pemerintah provinsi Jawa Timur sangat dominan. Karena semua yang bersangkutan terkait masjid secara tidak langsung akan dipertanggung jawabkan kepada Gubernur selaku dewan pembina. Namun pengangkatan pengelola oleh Pemerintahan Provinsi sangat disayangkan karena terlihat bahwa Kepala Bidang Keuangan merupakan pensiunan dari kantor gubernur dan dekat dengan para pejabat di pemerintahan.

Dari penuturan Kabid Keuangan dapat diketahui bahwa beliau tidak memiliki dasar pendidikan yang sama dengan pekerjaannya dan memiliki rangkap jabatan di organisasi lain yang bisa mengakibatkan kurang terfokusnya pekerjaan karena harus memikirkan urusan di tempat lain. Walaupun demikian dalam pengelolaan keuangan kabid keuangan sudah berpengalaman di berbagai organisasi keagamaan yang ada di Jawa Timur sehingga dipercaya lagi oleh gubernur untuk mengelola keuangan pada Masjid Al-Akbar Surabaya walaupun sudah pensiun. Dengan demikian sudah seharusnya gubernur selaku pimpinan tertinggi untuk bisa menempatkan orang-orang yang berkompeten dan masih dalam usia produktif untuk ditempatkan sebagai kabid keuangan.

Pegawai di Masjid Al-Akbar Surabaya sudah ada yang bekerja hingga belasan tahun oleh sebab itu sebaiknya gubernur memberikan kesempatan kepada karyawan yang memiliki kompetensi untuk bidang keuangan yang sudah mengabdikan dirinya selama belasan tahun, menjadi kabid keuangan seperti Bapak Alfian yang masih menjadi staf penerimaan dan akuntansi sejak 2001. Padahal seharusnya pemprov memberikan kesempatan untuk jenjang karir yang lebih baik untuk para pegawai yang sudah mengabdikan dirinya sejak lama di masjid tersebut.

Mekanisme pemberdayaan berupa jenjang karir yang jelas dalam organisasi masjid dalam penelitian ini tidak terbukti, dikarenakan penetapan 
pengurus inti dilakukan oleh Pemprov Jatim yang secara rinci tidak memahami permasalahan yang ada dalam internal masjid, karena Pemprov tidak memfasilitasi para karyawan untuk berkembang menduduki posisiposisi penting yang ada di pengelolaan masjid. Karena peneliti sangat meyakini bahwa banyak karyawan yang sudah sejak lama mengabdikan dirinya mampu untuk mengemban tugas tersebut, peneliti berpendapat bahwa jika ada dari internal yang mampu maka sudah selayaknya diberi kesempatan untuk bisa menjadi pengurus inti agar para karyawan tersebut merasa di hargai jerih payahnya serta terjadinya regenerasi dalam internal pengelolaan masjid Al Akbar.

\section{Akuntabilitas Proses}

Akuntabilitas proses yang berkaitan dengan proses administrasi dan pengawasan terhadap pengelolaan yang dilakukan oleh pengurus agar terciptanya kepercayaan oleh masyarakat terhadap pengelolaan yang dilakukan oleh pengelola MAS. Dalam proses penghitungan sedekah juga sudah memiliki SOP yang jelas terkait tata cara penghitungan kotak sedekah setiap minggunya.

Menurut standar operasional prosedur (SOP) Masjid Al-Akbar Surabaya No 03.2-SOP-01 tentang SOP penghitungan infaq kotak amal diawali dengan persiapan, mengelompokkan pecahan uang, merapikan uang dari lipatan, mensortir uang kertas, menghitung masing-masing pecahan, mencatat pada berita acara, penghitungan ulang dan pengantaran uang ketempat penyimpanan dengan pengewalan petugas keamanan.

Selain dari kotak infaq masyarakat juga bisa memberikan sedekahnya secara langsung kepada pihak masjid melalui UPT atau unit pelayanan terpadu. Masjid juga memberikan pelayanan yang maksimal untuk keperluan jamaah melalui unit pelayanan terpadu, masyarakat bisa memanfaatkan itu untuk mengetahui segala yang berkaitan dengan MAS. 
Dalam proses pengelolaannya masjid juga memiliki fasilitas yang disewakan untuk kepentingan umum seperti penyewaan gedung untuk resepsi pernikahan dengan proses dan prosedur dan biaya yang cukup jelas. Pengelola mesjid juga menyedakan unit pelayanan terpadu untuk melayani keperluan jamaah secara luas. Untuk itu proses dalam pendaftaran untuk kegiatan penyewaan gedung resepsi cukup mudah dan akan dilayani secara maksimal, namun diharapkan agar bisa mendaftar setahun sebelum kegiatan akan dilaksanakan, dikarenakan animo msyarakat sangat tinggi dalam melaksanakan kegiatan pernikahan di masjid. Mekanisme penggunaan fasilitas tersebut dapat dilihat seperti pada gambar 1.

Gambar 1. Mekanisme Penggunaan Fasilitas
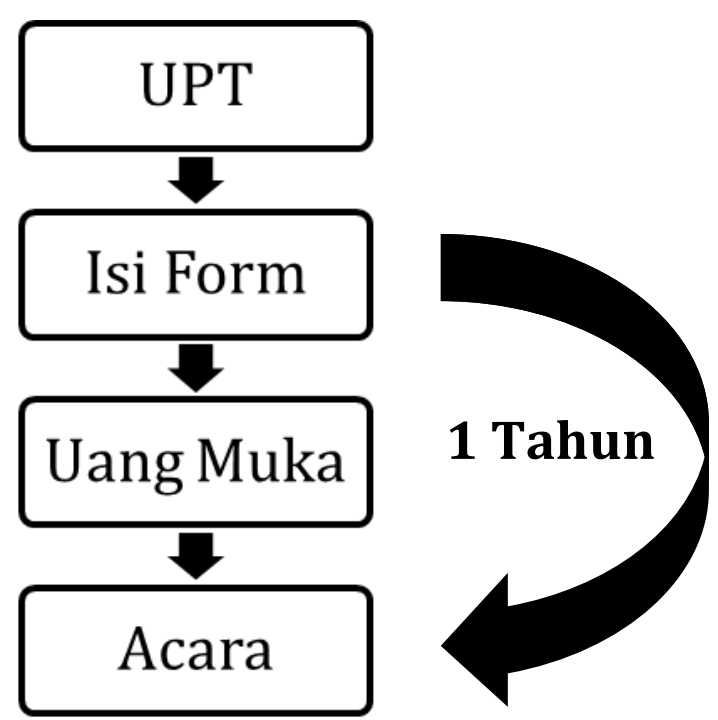

Dalam penentuan biaya dalam setiap penyelenggaraan resepsi pengelola sengaja mengenakan tarif yang telah disetujui pihak-pihak yang berkepentingan agar harganya tidak terlalu mahal dan masih bisa dijangkau. 
Keputusan dikenakannya biaya dalam penyewaan gedung resepsi pernikahan itu adalah untuk membiayai kebutuhan mesjid yang cukup besar. Semua itu di bawah tanggung jawab kepala bidang usaha dan humas.

Dalam akuntabilitas ini diketahui dalam proses pengelolaan mesjid juga masih ada ketidakseimbangan antara apa yang sudah dilakukan oleh pengurus mesjid dengan harapan yang diharapkan oleh jamaah, masih adanya keluhan-keluhan oleh jamaah menjadikan motivasi bagi pengurus untuk berusaha lebih baik lagi dalam pengelolaan MAS.

Selama ini para pengelola sudah berjuang dengan semaksimal mungkin, namun selalu ada saja keluhan dari jamaah dan ini menjadikan pengelola merasa menjadi duka karena terbebani oleh jamaah yang mengeluh. Pengelola juga sangat sadar akan kekurangannya tersebut dan akan dengan sungguh-sungguh melakukan perbaikan demi dapat melayani secara maksimal kepada jamaah,

Pada akuntabilitas ini juga dapat dilihat bagaimana hubungan yang erat antara pengelola dan jamaah masjid dalam melakukan berbagai kegiatan salah satunya saat mengumpulkan infak untuk korban bencana.

Dapat dilihat bagaimana komunikasi dan silaturahmi antara stewards dan jamaah terjalin cukup baik dan kepentingan antara manajer dan principal juga terjalin secara maksimal dengan selalu melibatkan dalam setiap kegiatan yang bersifat demi kepentingan umat, karena stewards yakin bahwa jika melibatkan para jamaah secara langsung maka akan memperlihatkan kepada semua pihak bahwa pengurus sudah menjalankan pengelolaannya secara maksimal dan terbuka, diharapkan jamaah bisa menjelaskan tentang pengelolaan masjid kepada jamaah lain secara langsung dan juga semua masukan dari jamaah juga di tindak lanjuti agar pengelolaan ke depan nya menjadi lebih baik lagi.

Penelitian ini sesuai dengan penelitian sebelumnya Siskawati, Ferdawati, dan Surya (2016) yang juga menemukan keterlibatan antara para 
jamaah dalam aktifitas masjid, dimana pihak pengelola melibatkan jamaah untuk setiap kegiatan seperti kegiatan sosial. Masyarakat diajak untuk ikut berpartisipasi agar masyarakat merasa memiliki masjid, dengan kata lain bahwa masjid juga merupakan tanggung jawab bersama untuk dimakmurkan. Semua itu adalah sikap sukarelawan dari jamaah secara bersama-sama dalam memakmurkan masjid.

Dalam melakukan observasi fasilita-fasilitas yang dimiliki oleh masjid sangatlah baik dan sangat terjaga, dimana selama observasi peneliti melihat terus menerusnya para petugas kebersihan membersihkan masjid untuk menjaga kebersihan dan kesucian masjid dan juga merapikan sesuatu yang dianggap bukan pada tempatnya, ini membuat jamaah merasa nyaman untuk berlama-lama di masjid. Karyawan MAS juga selalu diberikan kemampuan dalam skill dan keagamaannya untuk menunjang aktifitas pengelolaan sehari-hari.

Dari hasil ini ditemukan bahwa praktik akuntabilitas proses MAS berjalan sangat efektif karena jamaah selaku principal bisa secara langsung berperan aktif dan melihat secara langsung pengelolaan MAS serta selalu meningkatkan kemampuan skill dan keagamaan karyawannya, karena antara skill untuk bekerja dan ilmu agama harus seimbang, pengurus juga sangat terlihat perduli dimana pengurus masjid selalu menerima kritikan dan keluhan dari jamaah dan menjadi pengalaman untuk bisa diperbaiki lagi oleh pengurus demi kenyamanan principal atau jamaah.

\section{Akuntabilitas Program}

Akuntabilitas program adalah salah satu ujung tombak dari pada kemakmuran sebuah organisasi publik, program-program yang telah direncanakan setiap awal tahunnya akan memberikan kesiapan pengelola dalam melaksanakannya. Hasil observasi yang peneliti lakukan menemukan banyak kegiatan-kegiatan yang akan datang sudah dipublikasikan di mading masjid. Dari hasil amatan setelah shalat banyak masyarakat atau jamaah 
yang melihat pengumuman tersebut. Program yang diumumkan antara lain program ayo ngaji yaitu kajian Islam yang bisa diikuti oleh anak-anak dan dewasa. Dalam program mengaji tersebut diberikan pilihan kajian-kajian keilmuan seperti baca Al-Qur'an, tartil, tafsir, bahasa arab, tilawah dan menghafal Al-Qur'an.

Kemudian di mading tersebut juga dipublikasikan program lain seperti kegiatan hikmah Maulid yang dilaksanakan tanggal 11 Desember, tabligh akbar pada 16 Desember, khitanan massal pada 24 Desember, donor darah dan KB implan pada 13 Januari 2017, pengobatan gratis untuk poli umum, gigi gratis yang dilakukan Poliklinik Masjid. Bukan hanya itu program yang dilaksanakan pada saat peringatan-peringatan tertentu saja, namun banyak lagi program-program yang dilaksanakan oleh pengelola untuk melayani jamaah dan memberikan manfaat keada seluruh jamaah.

Gambar 2. Mekanisme Pengadaan Program

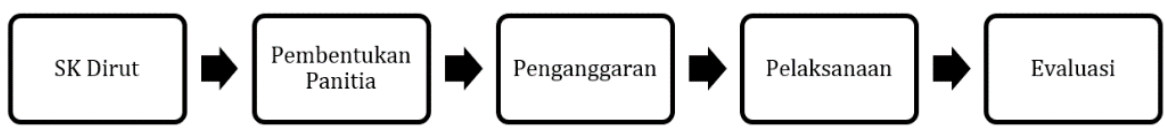

Mekanisme pengadaan program dapat dilihat pada gambar 2 dimana program yang dilaksanakan masjid selalu dibuatkan SK untuk setiap programnya, dimana langsung ditunjuk kepanitiaan dan penanggung jawab di setiap program acaranya. Setelah itu setiap bagian akan menganggarkan kebutuhannya untuk melaksanakan program, serta selalu diadakanya evaluasi setiap selesai kegiatan untuk bisa diambil pelajaran untuk program ke depannya sebagai program yang bisa menjadi prioritas di tahun berikutnya. Untuk membuat program sukses MAS selalu mempublikasikan acara yang akan diadakan melalui media radio, dan memang terbukti bisa terpublikasi.

Economica: Jurnal Ekonomi Islam - Volume 9, Nomor 2 (2018) 
MAS memiliki media informasi elektronik radio yang bernama SAS FM untuk menyiarkan semua kegiatan dan kepentingan masjid, selanjutnya juga dipublikasikan melalui SMS center, mading yang ada beberapa unit di berbagai sudut msajid serta media internet yaitu melalui situs resmi Masjid Al-Akbar Surabaya. Dari uraian di atas diketahui MAS sudah menjalankan program dengan baik dan terencana, dan mempublikasikan programprogramnya dengan baik, serta tata cara pelaksanaannya juga terlihat sangat baik dan sesuai dengan prosedur yang telah ditetapkan oleh Dirut.

Pimpinan MAS selalu memberikan motivasi bagi karyawannya untuk bisa sebaik mungkin dalam pengelolaannya, karena mereka harus sadar betul bahwa apa yang mereka dapatkan adalah semua itu dari jamaah, mereka bisa lebih sejahtera lagi jika masyarakat merasa puas dan tidak segan-segan untuk memberikan infaknya jauh lebih besar dari sebelumsebelumnya juga pengelola bisa memberikan kepuasan pelayanan kepada jamaah.

Secara umum stewards sudah mencoba dengan berbagai cara untuk terus bisa melaksanakan pengelolaannya secara maksimal untuk terciptanya kemaslahatan umat.

Dari akuntabilitas program dapat terlihat pengelolaan yang cukup baik dalam akuntabilitas ini dimana pimpinan berperan aktif untuk bisa memotivasi bagi seluruh karyawan untuk bisa lebih melayani jamaah secara luas dengan memberikan program-program yang berguna dan bermanfaat bagi seluruh jamaah.

\section{Akuntabilitas Kebijakan Keuangan}

Akuntabilitas keuangan merupakan sesuatu yang sangat sensitif pada suatu organisasi, karena menyangkut segala hal dalam proses operasional suatu organisasi. MAS pada tahun 2016 mengelola dana yang bersumber dari dana bantuan dan donatur, infak kotak, penggunaan fasilitas, infak dari 
lembaga pendidikan, zakat dan sedekah, dan lain-lain sesuai penuturan bagian keuangan.

Tahun 2016 dana yang dikelola berjumlah Rp. 13.970.818.095, dana yang cukup besar yang dikelola oleh masjid. Dalam pengelolaan keuangan masjid memiliki rencana dan realisasi anggaran penerimaan dan belanja yang disingkat dengan RAPBM. Dalam penggunaan dana Masjid Al Akbar tergolong sudah sangat baik dibuktikan dengan sudah terpisahnya antara bagian penerimaan dan penganggaran, di mana setiap pemasukan akan dicatat dan langsung diserahkan kepada bagian pengeluaran. Pada bagian pengeluaran juga pengawasannya cukup baik dimana bagian pengeluaran hanya bisa mengeluarkan uang secara langsung jika nominal uang tersebut tidak lebih dari Rp. 5.000.000, jika melebihi itu harus ada disposisi langsung dari kepala bidang keuangan agar bisa segera dicairkan.

Gambar 3. Mekanisme Pengeluaran Keuangan

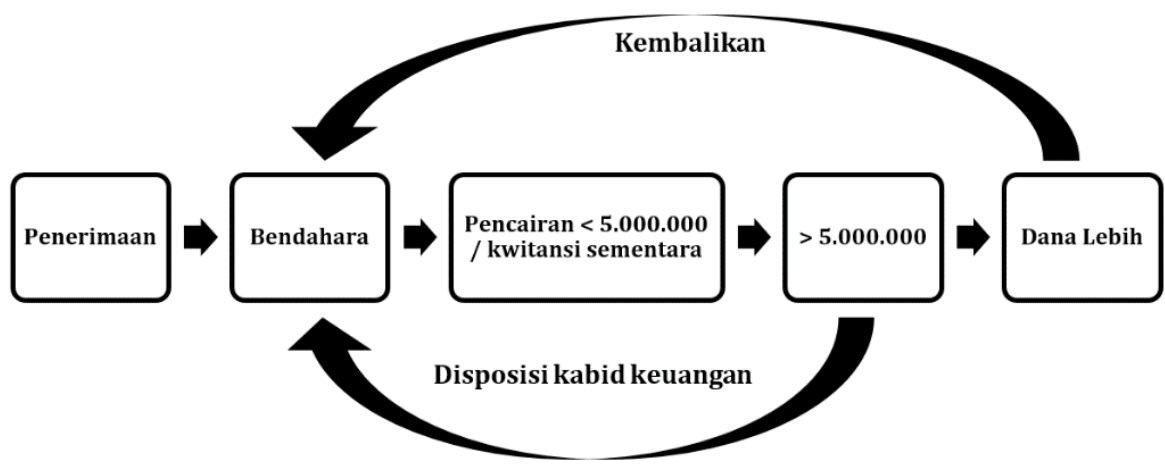

Penelitian ini bertentangan dengan penelitian Triyuwono and Roekhuddin (2000), yang meneliti pada lembaga amil zakat. Dalam penelitian tersebut ditemukan bahwa praktik pengendalian internalnya masih sangat lemah, dimana adanya rangkap jabatan antara bagian

Economica: Jurnal Ekonomi Islam - Volume 9, Nomor 2 (2018) 
Uun Dwi Al Muddatstsir, Dessy Noor Farida, Early Ridho Kismawadi

penerimaan dan pengeluaran. Hal tersebut sangat berpotensi untuk terjadinya tindakan-tindakan yang mengarah pada kejadian penyimpangan dalam pengelolaan keuangan.

Dalam pelaporannya MAS tergolong ke dalam organisasi yang modern dibandingkan dengan organisasi sejenis, yaitu sudah menggunakan aplikasi dalam pencatatan semua laporan keuangan.

Pada awalnya masjid tidak menggunakan aplikasi, sejak Bapak Alfian, staf akuntansi masuk di tahun 2001 pencatatannya masih secara manual yaitu hanya menggunakan microsoft excell, dengan perkembangan masjid yang cukup pesat dan transaksi keuangan yang cukup banyak maka dengan perlahan pengelola masjid mulai menyiapkan aplikasi untuk membantu dalam pelaporan keuangan dengan cara mengorder aplikasi yang khusus digunakan untuk kepentingan keuangan masjid. Namun hanya menggunakan alat bantu yaitu microsoft excell untuk mencatat segala aktifitas pengeluaran dan pemasukan masjid. Karena semakin banyaknya aktifitas di masjid maka pengurus berinisiatif untuk memesan aplikasi khusus buat kepentingan keuangan di mesjid sesuai yang dikatakan Bapak Alfian.

Penelitian ini sangat bertentangan dengan penelitian Simanjuntak dan Januarsi (2011) dimana dalam penelitiannya yang dilakukan di salah satu masjid di Tangerang, ditemukan bahwa pengelolaan dan pelaporan keuangannya sangat sederhana di mana pengelola hanya menggunakan sistem pelaporan keuangan secara tradisional yang hanya membuat empat kolom pelaporan yaitu kolom pengeluaran, pemasukan dan saldo dan pelaporannya juga tidak dilakukan secara konsisten dan periodik.

Pelaporan yang diaplikasikan pada masjid sudah mengadopsi PSAK 45 tentang entitas nirlaba sesuai dengan peraturan yang berlaku untuk organisasi seperti masjid. Dalam penelitian ini peneliti diberikan laporan keuangan berupa realisasi anggaran pendapatan belanja masjid, neraca, dan 
laporan surplus defisit yang tidak diberikan nominal. Masjid memang membuka laporannya namun bukan untuk dibuka-buka. Pihak masjid mempersilahkan untuk siapa pun yang ingin melihat laporannya bisa secara langsung untuk melihatnya. MAS membuat laporan keuangan yang meliputi laporan keuangan neraca, arus kas dan surplus defisit dan pada setiap hari Jum'at dipublikasikan kepada seluruh jamaah mesjid.

Namun hasil observasi peneliti bahwa pelaporan keuangan tidak disampaikan secara rinci pada layar yang ada di dalam masjid maupun dalam pengumuman. Pada saat pengumuman peneliti juga merekam sebagai bukti temuan bahwa hanya dan pengumuman total infak Jumat yang lalu tanpa perincian yang jelas seperti pada umumnya masjid, namun hanya mengumumkan pemasukan minggu lalu dan tata tertib pada saat pelaksanaan Jum'at seperti mengisi shaf, khatib yang akan khutbah serta pengumuman terkait program acara da'i cilik dan cerdas cermat, donor darah dan KB implan di parkir timur serta pengajian ahad pagi di ruang utama masjid.

Dalam melakukan pengamatan bahwa para pemberi sedekah yang memberikan sedekahnya langsung pada kotak amal maka tidak memiliki bukti kuat bahwa yang bersangkutan bersedekah secara formil. Namun jika jamaah mau memberikan sedekah secara formil maka pihak masjid mempersilahkan langsung untuk bisa diberikan kepada unit pelayanan terpadu dan akan diberikan bukti tanda terima sedekah tersebut secara formil agar memiliki bukti telah bersedekah. Hal in berguna untuk sebagai sistem pengawasan agar pemasukan masjid tercatat secara jelas.

Pengelolaan keuangan masjid dipertanggungjawabkan juga kepada Pemprov setiap tahunnya.Secara keseluruhan akuntabilitas keuangan yang diterapkan pengelola sudah sangat baik. Hal ini dibuktikan dengan perolehan sertifikasi bersifat internasional yaitu ISO 9001:2008. 
Masyarakat Jawa Timur harus berbangga karena masjid kebangaannya ini telah memiliki sertifikasi yang diakui secara internasional. Di Indonesia hanya ada dua masjid yang memilikinya salah satunya MAS. Peneliti juga sempat mencari info tentang masjid yang memperoleh ISO 9001:2008 bahwa ternyata benar Masjid Al Akbar adalah masjid kedua di Indonesia yang memperoleh sertifikasi tersebut. Selain Al Akbar, masjid yang pertama memperoleh sertifikasi tersebut adalah salah satu masjid yang tergolong bukan masjid yang terkenal di Jakarta yaitu masjid Al-Ikhlash Jati Padang yang terletak di Pasar Minggu, Jakarta Selatan. Masjid tersebut juga yang memperoleh pertama kali sertifikasi tersebut di Asia Tenggara.

Salah satu standar Sistem Manajemen Mutu (SMM) yang telah berkembang adalah ISO 9001 versi 2008 lebih mengutamakan pada pola business process yang terjadi dalam organisasi perusahaan. Dengan demikian hampir semua jenis usaha dapat mengimplementasikan sistem manajemen mutu ISO 9001 ini. Versi 2008 adalah versi terbaru yang diterbitkan pada Desember 2008 lalu. ISO 9001:2008 lebih mengedepankan pada efektivitas proses dari suatu organisasi (Hendartho 2018).

Dari akuntabilitas ini stewards selalu mempertimbangkan risiko-risiko yang akan terjadi. Terlihat bagaimana sikap pengelola mempertimbangkan risiko yang mungkin saja bisa diminimalisir dengan pengendalian internal dengan cara tetap diawasi dari pihak internal dan eksternal. Oleh sebab itu untuk meningkatkan kepercayaan publik, pengelola menerapkan pengawasan yang cukup ketat.

Penelitian ini bertentangan dengan penelitiannya Siskawati, Ferdawati, dan Surya (2016). Dengan menggunakan studi kasus peneliti menggali praktik akuntabilitas pada masjid Jami' Sungai Jambu, menemukan bahwa masjid yang dianggap salah satu masjid yang ada di Sumatera Barat ini masih lemah dalam pengelolaan kegiatannya, di mana internal kontrol yang ada dan pengawasan serta pengelolaan keuangan yang juga masih lemah. Sedangkan MAS memiliki sumber daya yang baik serta fasilitas penunjang 
dalam pengelolaan keuangannya seperti aplikasi untuk membuat laporan keuangan tersebut serta pengawasannya juga sudah dilakukan dengan baik.

Oleh karena itu akuntabilitas yang diterapkan oleh MAS sudah diakui oleh dunia internasional. Pengendalian secara internal dan eksternal juga telah dijalankan dengan baik. Oleh sebab itu prestasi tersebut sebaiknya terus dipertahankan demi terciptanya kepercayaan jamaah terhadap pengelola dalam mengelola MAS secara baik. Namun masih adanya kendala publikasi terkait keuangan menjadi permasalahan, sudah selayaknya pengurus mempublikasikan terkait keuangan di media yang dimiliki. Dari hasil amatan bahwa pengelola tidak mempublikasikan keuangan di media yang bisa diakses secara langsung oleh para jamaah, seharusnya pengelola bisa mempublikasikan di mading bahkan hingga di website resmi masjid agar masyarakat luas bisa mengakses secara langsung. Selama ini pengelola hanya mengizinkan secara terbatas terkait keuangan dengan secara langsung jamaah bisa menanyakan kepada pengelola di kantor.

Publikasi sangatlah penting sebagai bentuk pertanggungjawaban pengelola masjid Al Akbar kepada seluruh jamaah dan masyarakat agar pemikiran negatif yang selama ini beredar dapat dibuktikan dengan laporan terkait keuangan yang dipublikasikan dan dapat diakses oleh semua pihak yang memerlukannya.

Teori stedwardship dalam penelitian ini sangatlah terlihat dimana pengelola mengorbankan waktunya untuk kepentingan masjid bukan kepentingan individu serta pengelola terus memperbaiki pengelolaannya dengan selalu terbuka akan kritikan dan masukan yang diberikan oleh para jamaah masjid demi memakmurkan Masjid Al-Akbar Surabaya. 


\section{Simpulan}

Berdasarkan pembahasan di atas, maka dapat diambil kesimpulan dari penelitian ini adalah sebagai berikut:

1. Akuntabilitas kejujuran dan akuntabilitas hukum sudah berjalan dengan baik, hal ini terlihat dari pengelola tetap bertanggungjawab dalam mengelola masjid dan tetap ikhlas dan tulus dalam melayani masyarakat umum walaupun memiliki penghasilan yang cukup rendah dan tidak sebanding dengan apa yang telah mereka lakukan.

2. Akuntabilitas Proses juga sudah berjalan dengan baik, hal ini ditunjukkan dengan adanya peran aktif jamaan (principal) secara langsung dalam kegiatan masjid. Pengurus juga terlihat peduli dimana mereka menerima kritikan dan keluhan dari jamaah dan menjadikan kritikan tersebut sebagai upaya memperbaiki layanan lebih baik lagi demi kenyamanan jamaah.

3. Akuntabilitas program sudah berjalan efektif, hal ini terlihat dari peran aktif pimpinan dalam memotivasi seluruh karyawan untuk bisa melayani jamaan lebih baik dengan memberikan programprogram yang berguna dan bermanfaat bagi jamaah.

4. Akuntabilitas kebijakan keuangan juga sudah berjalan dengan cukup baik. Hal ini terlihat dari pencatatan laporan keuangan yang dilakukan MAS sudah menggunakan aplikasi. Dan pelaporannya sudah sesuai dengan PSAK 45 tentang entitas nirlaba.

5. Secara keseluruhan akuntabilitas MAS sudah sangat baik disebabkan karena akuntabilitas yang dihasilkan sudah terdokumentasi dan sesuai dengan SOP yang ada serta ditunjukkan kepada jamaah sebagai principle bahkan melibatkan secara langsung dalam beberapa aktivitasnya dan juga pertanggungjawabannya sudah dilaporkan kepada Pemprov Jawa Timur. Namun masih ditemukannya kelemahan dimana direksi dan Gubernur tidak bisa 
memberdayakan internal pegawai untuk berada pada posisi kabid keuangan sehingga kabid keuangan berasal dari pihak eksternal organisasi, dengan usia pensiun serta memiliki rangkap jabatan di organisasi lain yang bisa mengganggu kinerjanya di masjid karena tidak fokus.

Terkait publikasi juga pengelola masjid Al Akbar belum mampu memaksimalkan untuk mempublikasikan terkait keuangan masjid. Selayaknya pengelola dapat mempublikasikan di seluruh media yang ada termasuk pada website resminya agar bisa diakses semua pihak dan masyarakat sehingga mereka bisa melihat secara langsung dan tidak berfikiran negatif terhadap pengelola.

Teori Stewardship berlaku pada pengelolaan masjid, dimana pengelola benar-benar melakukan pengelolaannya secara maksimal dan penuh dengan rasa tanggung jawab dan tanpa pamrih, yaitu tanpa memperdulikan apa yang akan diperoleh sesudah melaksanakan, bahkan pengelola secara ikhlas menerima pendapatan yang diberikan MAS ataupun tidak diberikan sama sekali, karena mereka memiliki prinsip melayani jamaah dan bekerja sebagai ibadah bukan bekerja.

\section{Daftar Pustaka}

Basuki. 2016. Metode Penelitian Akuntansi Dan Manajeman Berbasis Studi Kasus. surabaya: airlangga University Press.

Donaldson, Lex, and James H. Davis. 1991. "Stewardship Theory or Agency Theory: CEO Governance and Shareholder Returns." Australian Journal of Management 16 (1): 49-64. https://doi.org/10.1177/031289629101600103.

Ebrahim, Alnoor. 2003. "Accountability In Practice: Mechanisms for NGOs." World Development 31 (5): 813-29. https://doi.org/10.1016/S0305750X(03)00014-7. 
Ellwood, Sheila. 1993. "Parish and Town Councils: Financial Accountability and Management." Local Government Studies 19 (3): 368-86. https://doi.org/10.1080/03003939308433687.

Hanafi, Roby. 2015. "Akuntabilitas Dan Pengelolaan Keuangan Masjid Melalui Pendekatan Fenomenologi (Studi Empiris Pada Masjid Nurusy Syifa' Surakarta)."

Hendartho, Dony. 2018. "Analisis Implementasi Sistem Manajemen Mutu ISO 9001:2008 Pada Sekolah Tinggi Ilmu Administrasi Mandala Indonesia." Transparansi Jurnal Ilmiah Ilmu Administrasi 6 (2): 124-38. https://doi.org/10.31334/trans.v6i2.37.

Kaihatu, Thomas S. 2006. "Good Corporate Governance Dan Penerapannya Di Indonesia." Jurnal Manajemen Dan Kewirausahaan 8 (1): 1-9. https://doi.org/10.9744/jmk.8.1.pp. 1-9.

Kamayanti, Ari. 2016. Metodologi Penelitian Kualitatif Akuntansi: Pengantar Religiositas Keilmuan. Yayasan Rumah Peneleh.

Kiswanto, Kiswanto, and Hasan Mukhibad. 2011. "Analisis Budaya Islam Dan Akuntabilitas." Jurnal Dinamika Akuntansi 3 (2). https://doi.org/10.15294/jda.v3i2.1947.

Mardiasmo. 2000. Akuntansi Sektor Publik. yogyakarta: andi.

Mardiasmo, Mardiasmo. 2006. "Perwujudan Transparansi Dan Akuntabilitas Publik Melalui Akuntansi Sektor Publik: Suatu Sarana Good Governance." Jurnal Akuntansi Pemerintah 2 (1).

Putri, Ayuko Bunga Pertiwi. 2013. "Akuntabilitas Dalam Perspektif Pondok Pesantren (Studi Fenomenologi Pada Pondok Pesantren Mamba'us Sholohin Gresik)." UNIVERSITAS AIRLANGGA. http://repository.unair.ac.id/442/.

Randa, Fransiskus, Iwan Triyuwono, Unti Ludigdo, and Eko Ganis Sukoharsono. 2011. "Studi Etnografi Akuntabilitas Spiritual Pada Organisasi Gereja Katolik Yang Terinkulturasi Budaya Lokal." Jurnal Akuntansi Multiparadigma 2 (1): 35-51. https://doi.org/10.18202/jamal.2011.04.7109.

S, Adebayo O., Ayeni Gabriel Olusola, and Oyewole Felicia Abiodun. 2013. "Relationship Between Corporate Governance And Organizational Performance: Nigerian Listed Organizations Experience." International Journal of Business and Management Invention 2 (9): 1-6. 
Sari, Meriska, Sri Mintarti, and Yunita Fitria. 2018. "Akuntabilitas Pengelolaan Keuangan Organisasi Keagamaan.” Kinerja 15 (2): 45. https://doi.org/10.29264/jkin.v15i2.4029.

Simanjuntak, Dahnil Anzar, and Yeni Januarsi. 2011. "Akuntabilitas Dan Pengelolaan Keuangan Di Masjid." In Simposium Nasional Akuntansi. http://pdeb.fe.ui.ac.id/?p=5670.

Siskawati, Eka, Ferdawati Ferdawati, and Firman Surya. 2016. "Pemaknaan Akuntabilitas Masjid: Bagaimana Masjid Dan Masyarakat Saling Memakmurkan?" Jurnal Akuntansi Multiparadigma 7 (1): 70-80. https://doi.org/10.18202/jamal.2016.04.7006.

Sugiyono. 2012. Metode Penelitian Kuantitatif Kualitatif Dan R\&D. Alfabeta. http://onesearch.id/Record/IOS2726.slims-73890.

Triyuwono, Iwan, and Roekhuddin Roekhuddin. 2000. "Konsistensi Praktik Sistem Pengendalian Intern Dan Akuntabilitas Pada Lazis (Studi Kasus Di Lazis X Jakarta)." The Indonesian Journal of Accounting Research 3 (2). http://ijar-iaikapd.or.id/index.php/ijar/article/view/43. 
